\title{
Cesarean scar pregnancy management: medical or surgical? When and which? A literature review
}

\author{
Postępowanie w przypadku ciąży w bliźnie po cięciu cesarskim: leczenie farmakologiczne \\ czy chirurgiczne? Kiedy i jak? Przegląd piśmiennictwa
}

\author{
Gynecologic Oncology Clinic, Tepecik Education and Research Hospital, Izmir, Turkey \\ Correspondence: Gülşah Selvi Demirtaş, Gynecologic Oncology Clinic, Tepecik Research and Education Hospital, 35000 Izmir, Turkey, tel.: +905337271512, e-mail: drg.selvi@gmail.com
}

\begin{abstract}
Aim: The aim of this study was to compare the effectiveness of treatment methods and to highlight treatment debates of cesarean scar pregnancy in the light of the current literature. Materials and methods: A total of 55 cesarean scar pregnancy patients from 39 English, free full-text available case reports published between year 2010 and 2020 were analyzed. The patients were treated with various treatment methods. The most commonly used methods, complications, and treatment failures were evaluated. Cases with uterine dehiscence, rupture, acute abdomen, placental abnormalities, trophoblastic diseases, heterotopic pregnancies, twin pregnancies, and emergency surgeries were excluded from the analysis. Results: Overall, 55 patients from 39 case reports were included in the analysis. Of these cases, 24 were treated with methotrexate (14 patients systemically, 9 systemically methotrexate plus local potassium chloride, 1 methotrexate plus mifepristone). Surgical management was performed in 31 patients, and involved: dilatation and suction curettage, laparoscopy, uterine artery embolization, laparotomy, hysteroscopy, high intensity focused ultrasound, bilateral uterine artery balloon catheter insertion, obliteration of the feeding artery with fibrin sealant, and cesarean section. Two of the cesarean scar pregnancies were continued and cesarean section plus hysterectomy was performed at 35 weeks gestation. Limitations of the study: Dependence of the analysis on anecdotal case reports and series is the main limitation of this study. Therefore, there is a need for larger prospective series comparing treatment options and outcomes. Another limitation that precludes us from definitive conclusions is the heterogeneity in the methods of laboratory measurements, the quality of ultrasonography equipment, and the experience of surgeons. Conclusion: In conclusion, although there has been no established consensus on the management of scar line pregnancies in the literature, current literature indicates that one size does not fit and that it is reasonable to plan the treatment according to the patients' characteristics. Ultrasonography is valuable in diagnosis and choosing a treatment modality. It is also crucial to determine the type of scar line pregnancy before planning the treatment.
\end{abstract}

Keywords: cesarean section, ectopic pregnancy, cesarean scar pregnancy

Cel: Celem badania było porównanie skuteczności metod leczenia ciąży w bliźnie po cięciu cesarskim ze szczególnym uwzględnieniem dyskusji dotyczących strategii terapeutycznych w świetle aktualnej literatury. Materiał i metody: Analizą objęto łącznie dane 55 pacjentek z rozpoznaniem ciąży w bliźnie po cięciu cesarskim z 39 dostępnych angielskojęzycznych pełnotekstowych opisów przypadków opublikowanych w latach 2010-2020. Pacjentki leczono z zastosowaniem różnych metod. Ocenie poddano najczęściej stosowane metody leczenia, powikłania oraz niepowodzenia terapeutyczne. $Z$ analizy wykluczono przypadki rozejścia się macicy, pęknięcia macicy, ostrego brzucha, nieprawidłowości łożyska, chorób trofoblastycznych, ciąży bliźniaczej oraz zabiegów ze wskazań nagłych. Wyniki: Łącznie analizą objęto 55 pacjentek (39 opisów przypadków), w tym 24 pacjentki leczone metotreksatem (leczenie ogólnoustrojowe u 14, leczenie ogólnoustrojowe metotreksatem i miejscowe chlorkiem potasu u 9 pacjentek oraz leczenie metotreksatem i mifepristonem u 1 pacjentki). Leczenie operacyjne przeprowadzono u 31 kobiet i obejmowało ono: rozszerzenie i wyłyżeczkowanie próżniowe, laparoskopię, embolizację tętnicy macicznej, laparotomię, histeroskopię, technologię HIFU (zogniskowanej fali ultradźwiękowej o wysokiej częstotliwości), wprowadzenie balonu cewnika obustronnie do tętnic macicznych, obliterację tętnicy doprowadzającej klejem fibrynowym oraz cięcie cesarskie. Dwie ciąże w bliźnie po cięciu cesarskim kontynuowano do 35. tygodnia ciąży, w którym wykonano cięcie cesarskie z histerektomią. Ograniczenia badania: Głównym ograniczeniem badania było oparcie analizy na niepotwierdzonych opisach przypadków i seriach przypadków. Potrzebne są większe badania prospektywne dotyczące serii przypadków, porównujące różne opcje i wyniki leczenia. Kolejnym ograniczeniem, które nie pozwoliło na wyciągnięcie ostatecznych wniosków, był brak jednorodności w odniesieniu do metod pomiarów laboratoryjnych, 
jakości sprzętu ultrasonograficznego i doświadczenia chirurgów. Wniosek: Podsumowując, pomimo braku ustalonego konsensusu dotyczącego postępowania w przypadku ciąży w bliźnie po cięciu cesarskim w piśmiennictwie, z przeglądu aktualnej literatury wynika, że nie ma rozwiązań uniwersalnych, a zatem uzasadnione jest planowanie leczenia zgodnie z indywidualną charakterystyką pacjentki. Ultrasonografia jest cennym narzędziem w diagnostyce i wyborze metody leczenia. Istotne jest również określenie rodzaju ciąży w bliźnie po cięciu cesarskim przed planowaniem leczenia.

Słowa kluczowe: cięcie cesarskie, ciąża ektopowa, ciąża w bliźnie po cięciu cesarskim

\section{INTRODUCTION}

${ }^{\mathrm{t}}$ esarean scar pregnancy (CSP) is a rare but unique and life-threatening type of ectopic pregnancy. This type of pregnancy was first defined by Larsen and Solomon ${ }^{(1)}$. One explanation of the pathophysiology includes disruption of the normal healing process of the isthmic wall by repeated trauma and poor vascularization in the scar that prevents optimal healing ${ }^{(2)}$. Cervical dilation in labor, prolonged duration of labor, or oxytocin augmentation are also considered factors that increase the risk of a large scar defect in non-pregnant women ${ }^{(3)}$. Along with the rising rate of cesarean section and improvements in sonographic imaging, the incidence of CSP has substantially increased worldwide ${ }^{(4-7)}$. CSP diagnosis has a critical importance due to its life-threatening feature. Undiagnosed ectopic pregnancy of any abnormal location remains an important cause of pregnancy-related deaths ${ }^{(8)}$. In the literature, several etiopathogenetic explanations were proposed. One of these is the suturing and closure technique. Roberge et al. reported that a locked single-layer suturing technique is associated with a fourfold increase in the risk of uterine rupture compared with the double-layer suturing technique ${ }^{(9)}$. Since no standard management protocol has been established for this rare life-threatening condition, each patient should be evaluated individually ${ }^{(10)}$. In this type of ectopic pregnancy, the gestational sac is partially or completely implanted in the cesarean section scar $^{(11)}$.

Vial et al. reported two different types of CSP: The first type is a superficial invasion of the amniotic sac into the scar with the progression of pregnancy into the cervicoisthmic space and uterine cavity, which is known as endogenous CSP (type I). The second type involves a deep implantation into the scar with progression toward the uterine myometrium and the serosal surface, and is referred to as exogenous CSP (type II) ${ }^{(12)}$. This type is particularly dangerous due to high risk of uterine rupture and hemorrhage ${ }^{(13)}$. Besides, management options for these types of CSP have not been established yet ${ }^{(14)}$. Therefore, a guideline is needed to establish a standardized safe and effective management. In this literature review, the effectiveness of treatment methods was compared and the debates on the management were highlighted.

\section{MATERIALS AND METHODS}

A total of 55 cesarean scar pregnancy (CSP) patients from between 2010 and 2020 were analyzed. Reviews and clinical trials were excluded. Patients were treated with various treatment methods. The most commonly used treatment methods, complications, and treatment failures were evaluated. Cases with uterine dehiscence, rupture, acute abdomen, placental abnormalities, trophoblastic diseases, heterotopic pregnancies, twin pregnancies, and emergency surgeries were excluded from the analysis.

\section{Treatment methods}

Local or systemic injection of methotrexate (MTX) has been widely used for medical treatment. Local treatment is considered to be more effective than systemic treatment ${ }^{(15)}$. Besides, medical treatment is not preferred in some situations. Advanced gestational age, high level of serum $\beta$-subunit of hCG gonadotropin (beta-hCG), and positive fetal cardiac activity. The type of CSP is also important for selecting the candidates. Unfortunately, there are no established management protocols depending on the type of CSP. Surgical treatment includes dilatation and suction curettage $(\mathrm{C})$, laparoscopy $(\mathrm{L} / \mathrm{S})$, uterine artery embolization (UAE), laparotomy (L/T), hysteroscopy (H/S), high-intensity focused ultrasound (HIFU), bilateral uterine artery balloon catheter insertion, obliteration of feeding artery with fibrin sealant, and hysterectomy.

\section{RESULTS}

All patients in this analysis were hemodynamically stable and had no acute abdomen during admission to the hospital. In all cases, the diagnosis was made based on ultrasound examination. In 45 patients, an embryo with a cardiac activity was documented. Among all, 24 patients were treated with MTX [14 patients systemically, 9 systemically MTX, and local potassium chloride (KCL), 1 MTX and mifepristone]. Surgical treatment included dilatation and C, L/S, UAE, L/T, $\mathrm{H} / \mathrm{S}$, HIFU, bilateral uterine artery balloon catheter insertion, obliteration of the feeding artery with fibrin sealant, cesarean section. One of the reports documents a 41-year-old CSP patient with a live birth. At 38 weeks, the baby was safely delivered during a three-hour-long cesarean section operation. Placenta previa was observed. Hysterectomy was performed after delivery due to the massive bleeding. In another case report of a 32-year-old patient, pregnancy was continued and cesarean section was performed with hysterectomy at 35 weeks gestation due to bleeding. 


\begin{tabular}{|l|c|c|c|}
\hline $\begin{array}{l}\text { Conservative } \\
\text { treatment }\end{array}$ & $\begin{array}{c}\text { Number of } \\
\text { patients }\end{array}$ & $\begin{array}{c}\text { Treatment } \\
\text { failure }\end{array}$ & Complication \\
\hline Only MTX: & 3 & & \\
- local & 10 & 2 & 0 \\
- systemic & 1 & 0 & 0 \\
- local + systemic & 14 & $4(28.5 \%)$ & 0 \\
Total & 9 & 0 & 0 \\
\hline MTX + KCL & 1 & 0 & 0 \\
\hline MTX + mifepristone & 10 & 0 \\
\hline MTX - methotrexate; KCL - potassium chloride. \\
\hline
\end{tabular}

Tab. 1. Conservative treatments with MTX

\begin{tabular}{|c|c|c|c|}
\hline Surgical treatment & $\begin{array}{c}\text { Number of } \\
\text { patients }\end{array}$ & $\begin{array}{c}\text { Treatment } \\
\text { failure }\end{array}$ & Complication \\
\hline $\begin{array}{l}\text { C: } \\
\cdot \text { only C } \\
\text { - C+ MTX } \\
\text { - C + Foley catheter } \\
\text { Total }\end{array}$ & $\begin{array}{l}1 \\
4 \\
1 \\
6\end{array}$ & $\begin{array}{c}1(100 \%) \\
0 \\
0 \\
1(100 \%)\end{array}$ & $\begin{array}{l}0 \\
0 \\
0 \\
0\end{array}$ \\
\hline $\begin{array}{l}\text { L/S: } \\
\cdot \text { only L/S } \\
\cdot \text { L/S + MTX } \\
\cdot \text { L/S + vasopressin } \\
\cdot \text { L/S + UAE } \\
\text { Total } \\
\end{array}$ & $\begin{array}{c}6 \\
1 \\
2 \\
1 \\
10 \\
\end{array}$ & $\begin{array}{c}1(16.6 \%) \\
0 \\
0 \\
0 \\
1 \\
\end{array}$ & $\begin{array}{l}0 \\
0 \\
0 \\
0 \\
0 \\
\end{array}$ \\
\hline $\mathrm{L} / \mathrm{T}$ & 3 & 0 & 0 \\
\hline $\mathrm{H} / \mathrm{S}+\mathrm{MTX}$ & 1 & 0 & 0 \\
\hline $\begin{array}{l}\text { UAE: } \\
\text { - UAE + MTX } \\
\text { - UAE + L/S + H/S } \\
\text { - UAE + C } \\
\text { Total }\end{array}$ & $\begin{array}{l}1 \\
1 \\
1 \\
3 \\
\end{array}$ & $\begin{array}{l}0 \\
0 \\
0 \\
0\end{array}$ & $\begin{array}{l}0 \\
0 \\
1 \\
1 \\
\end{array}$ \\
\hline $\begin{array}{l}\text { HIFU: } \\
\cdot \text { HIFU + C + MTX } \\
\text { - HIFU + } \\
\text { mifepristone } \\
\text { Total }\end{array}$ & $\begin{array}{l}3 \\
1 \\
4 \\
\end{array}$ & $\begin{array}{c}1(33.3 \%) \\
0 \\
1(33.3 \%) \\
\end{array}$ & $\begin{array}{l}0 \\
0 \\
0\end{array}$ \\
\hline $\begin{array}{l}\text { Local MTX + KCL + } \\
\text { bil. UABCI +C+ } \\
\text { Foley catheter }\end{array}$ & 1 & 1 & 0 \\
\hline OFAFS & 1 & 0 & 0 \\
\hline C/S + hysterectomy & 2 & 0 & 0 \\
\hline
\end{tabular}

C - suction curettage; MTX - methotrexate; L/S - laparoscopy; UAE - uterine artery embolization; L/T - laparotomy; H/S - hysteroscopy; HIFU - highintensity focused ultrasound; $\mathbf{K C L}$ - potassium chloride; bil. $\mathbf{U A B C l}$ - bilateral uterine artery balloon catheter insertion; OFAFS - obliteration of the feeding artery with fibrin sealant; $\mathbf{C} / \mathbf{S}$ - cesarean section.

\section{Tab. 2. Surgical treatments}

The rates of treatment failures are shown in Tabs. 1 and 2 . The most frequently used treatments, i.e. MTX and laparoscopy, were also compared in terms of outcome (Tabs. 3 and 4). They were found to be comparable with respect to success rates $(p=0.9)$. Medical and surgical treatments were compared in terms of treatment failure, but no statistical significance was detected ( $p=0.273$ ). Also, the comparison of treatment types in terms of beta-hCG levels, cesarean section number, abortion number, parity, and gravida, revealed no statistically significant differences $(p=1, p=0.249, p=0.207, p=0.289, p=0.105$, respectively).

\begin{tabular}{|l|c|c|}
\hline & $\begin{array}{c}\text { Successful } \\
(\boldsymbol{n}=\mathbf{8})\end{array}$ & $\begin{array}{c}\text { Unsuccessful } \\
(\boldsymbol{n}=\mathbf{2})\end{array}$ \\
\hline Maternal age & $29.6 \pm 3.8$ & $35 \pm 3$ \\
\hline Gravidity & $4 \pm 1.65$ & $4 \pm 0$ \\
\hline Parity & $3.25 \pm 1.47$ & $3 \pm 0$ \\
\hline Prior C/S number & $2.125 \pm 0.78$ & $3 \pm 0$ \\
\hline Gestational age [week] & $5.87 \pm 0.59$ & $7.5 \pm 2.5$ \\
\hline Beta-hCG & $36.999 \pm 1368.9$ & $42.389 \pm 22.746$ \\
\hline $\begin{array}{l}\text { Data are presented as mean } \pm \text { standard deviation. } \\
\text { hCG - human chorionic gonadotropin. }\end{array}$ \\
\hline
\end{tabular}

Tab. 3. Cesarean section ectopic pregnancies primarily treated only with systemic methotrexate

\begin{tabular}{|l|c|c|}
\hline & $\begin{array}{c}\text { Successful } \\
(\boldsymbol{n}=\mathbf{5})\end{array}$ & $\begin{array}{c}\text { Unsuccessful } \\
(\boldsymbol{n}=\mathbf{1})\end{array}$ \\
\hline Maternal age & $31.8 \pm 3.31$ & 36 \\
\hline Gravidity & $3.8 \pm 2.71$ & 5 \\
\hline Parity & $1.6 \pm 0.8$ & 2 \\
\hline Prior C/S number & $1.6 \pm 0.8$ & 2 \\
\hline Gestational age [week] & $8 \pm 1.89$ & 6 \\
\hline Beta-hCG & $39.9394 \pm 33.64512$ & 21.521 \\
\hline $\begin{array}{l}\text { Data are presented as mean } \pm \text { standard deviation. } \\
\text { hCG }- \text { human chorionic gonadotropin. }\end{array}$ \\
\hline
\end{tabular}

Tab. 4. Cesarean section ectopic pregnancies primarily treated only with laparoscopy

\begin{tabular}{|l|c|c|c|}
\hline Treatment methods & Successful & Unsuccessful & Total \\
\hline Systemic MTX only & 8 & 2 & 10 \\
\hline L/S only & 5 & 1 & 6 \\
\hline Others & 32 & 7 & 39 \\
\hline Total & 45 & 10 & 55 \\
\hline
\end{tabular}

Tab. 5. Comparison of MTX and L/S treatments by success rates

\section{DISCUSSION}

The present study had several limitations. First, this was a literature review of the available cases. The type of CSP was not reported in all cases. The cut-off value of serum beta-hCG might be different in different settings. CSP types were mentioned in only 9 patients out of 55 case reports. But in all type 2 patients $(n=6)$, an initial medical treatment was performed, followed by a conversion to surgery due to rising levels of beta-hCG.

CSP can easily be misdiagnosed in early pregnancy. In this situation, blind induced abortion may result in uncontrolled hemorrhage. Therefore, transvaginal ultrasonography is crucial in early pregnancy to rule out CSP. The ultrasonographic diagnostic criteria have been defined; a CSP is diagnosed when the uterine cavity and the cervical canal are empty, and the gestational sac is located in the anterior portion of the uterine isthmus ${ }^{(16)}$.

In this study, ultrasonographic examination was used as a diagnostic tool in all cases. Jurkovic et al. reported that 
$72 \%$ of their CSP patients had undergone multiple $(\geq 2)$ CS procedures. They reported that multiple CS procedures led to poor healing of the uterine incision, which was a highrisk factor for $\mathrm{CSP}^{(17)}$. In this study, the $\mathrm{C}$-section number was mentioned in 50 out of 55 cases. In was not reported in 5 case reports. Out of 50 cases, 28 (56\%) patients had undergone multiple $(\geq 2)$ CS procedures.

When evaluating a pregnant patient with vaginal bleeding or abdominal pain, it is important to consider ectopic pregnancy, especially if the patient has a history of multiple previous cesarean sections. There are two types of cesarean scar ectopic pregnancy. It is important to determine this type during ultrasound examination. The first type can proceed to term with a viable fetus, with an increased risk of postpartum hemorrhage ${ }^{(18)}$. The second type carries the risk of rupture and hemorrhage during the first trimester. Management options for these CSP types have not been established ${ }^{(14)}$. There is no universal agreement on the optimal treatment modality for CSP. It is considered that MTX treatment is effective when serum Bhcg levels are lower than $5000 \mathrm{mIU} / \mathrm{mL}^{(12)}$. Seow et al. reported that up to 8 weeks of pregnancy with no fetal heart activity, a single i.m. dose of $50 \mathrm{mg} / \mathrm{m}^{2}$ may be safe in CSP treatment ${ }^{(19)}$. HaimovKochman et al. reported 18 patients up to 8 weeks of pregnancy who were treated with MTX and 6 patients after 8 weeks who were treated with surgical treatment. In this study, the authors stated that systemic MTX administration is insufficient due to the poorer drug penetration in the fibrous tissue ${ }^{(20)}$. Sel et al. used a vacuum extraction under ultrasound guidance for CSP series ${ }^{(21)}$. In this study, selection criteria for vacuum extraction were: pregnancies $<8$ weeks gestation, beta-hCG level $<10,000 \mathrm{mIU} / \mathrm{mL}$, hemodynamically stable patients, no sign of uterine rupture. Patients who did not meet the criteria for vacuum extraction were treated with intramuscular MTX plus vacuum extraction technique if they were hemodynamically stable. The authors stated that the vacuum evacuation method is a feasible treatment for CSP. With the vacuum evacuation method, adjuvant use of an inflatable foley balloon catheter to treat or restrain massive blood loss has been reported ${ }^{(22,23)}$. In a study reported by Kim et al., MTX treatment alone as a first-line therapy showed a low success rate ${ }^{(24)}$.

\section{When to suspect CSP?}

Sonography is the first-line diagnostic tool for cesarean scar pregnancy. CSP should be suspected based on the following criteria ${ }^{(25)}$ : empty uterine cavity and closed empty cervical canal, placenta and/or gestational sac embedded in the cesarean section scar, thin (1-3 mm) or absent myometrial layer between the gestational sac and the bladder, the presence of embryonic/fetal pole and/or yolk sac with or without heart activity, the presence of a prominent and, at times, rich vascular pattern at or in the area of a cesarean section scar in the presence of a positive pregnancy test and a negative sliding organs sign.

\section{Which treatment?}

This study has some limitations. Sample size was the major limitation, which prevented us from claiming that any of the described techniques to be universally applicable to all patients with CSP. But as stated in the literature, the diagnosis should be followed by determination of the type of CSP. In the second type, we must be aware of the high risk of rupture if the pregnancy continues. Patients with this type should be appropriately informed. Although management options for these types of CSP have not been established, especially after 8 weeks gestation and with positive fetal cardiac activity, unstable hemodynamic state, serum beta-hCG of more than 5,000 mIU/mL, it should be kept in mind that medical treatment used as the first-line approach often needs additional surgical interventions. A combination of medical and operative treatment is considered to increase the success of treatment.

Surgical treatment modalities may be undertaken in hemodynamically unstable patients or when pharmacological treatment proves ineffective. Operative methods include laparotomy, laparoscopy, hysteroscopy, uterine artery embolization, high intensity focused ultrasound, obliteration of the feeding artery with fibrin sealant, hysteroscopy, and curettage with gestational sack suction. Combination of medical and operative treatment can increase the success of treatment.

In conclusion, based on the cases described in the literature, transvaginal sonography is an important tool in diagnosing CSP, especially patients with vaginal bleeding and abdominal pain. CSP is a product of cesarean section and is associated with multiple factors. Once it is diagnosed, early termination of pregnancy is extremely important to avoid serious complications. The knowledge of the CSP type is essential for the determination of the risk of rupture and hemorrhage. In the management of CSP, medical treatment (particularly not with MTX alone) is effective in most of the cases as first line treatment. However, surgical interventions and combination of medical and surgical treatments should be used in hemodynamically unstable patients or in the case of medical treatment failure.

\section{Conflict of interest}

The authors do not report any financial or personal connections with other persons or organizations, which might negatively affect the contents of this publication and/or claim authorship rights to this publication. 


\section{References}

1. Larsen JV, Solomon MH: Pregnancy in a uterine scar sacculus an unusual cause of postabortal haemorrhage. A case report. S Afr Med J 1978; 53: 142-143.

2. Ofili-Yebovi D, Ben-Nagi J, Sawyer E et al.: Deficient lower-segment Cesarean section scars: prevalence and risk factors. Ultrasound Obstet Gynecol 2008; 31: 72-77.

3. van der Voet LF, de Vaate B, Veersema S et al.: Long-term complications of caesarean section. The niche in the scar: a prospective cohort study on niche prevalence and its relation to abnormal uterine bleeding. BJOG 2014; 121: 236-244.

4. Martin JA, Hamilton BE, Osterman MJK et al.: Births: final data for 2013. Natl Vital Stat Rep 2015; 64: 1-65.

5. Dietz HP, Campbell S: Toward normal birth - but at what cost? Am J Obstet Gynecol 2016; 215: 439-444.

6. Timor-Tritsch IE, Monteagudo A: Unforeseen consequences of the increasing rate of cesarean deliveries: early placenta accreta and cesarean scar pregnancy. A review. Am J Obstet Gynecol 2012; 207: 14-29.

7. Birge Ö, Karaca C, Arslan D et al.: Medical management of cesarean scar pregnancy at advanced age: case report and literature review. Clin Exp Obstet Gynecol 2016; 43: 140-142.

8. Dibble EH, Lourenco AP: Imaging unusual pregnancy implantations: rare ectopic pregnancies and more. AJR Am J Roentgenol 2016; 207: 1380-1392.

9. Roberge $S$, Demers $S$, Berghella $V$ et al.: Impact of single- vs double-layer closure on adverse outcomes and uterine scar defect: a systematic review and metaanalysis. Am J Obstet Gynecol 2014; 211: 453-460.

10. Rotas MA, Haberman S, Levgur M: Cesarean scar ectopic pregnancies: etiology, diagnosis, and management. Obstet Gynecol 2006; 107: 1373-1381.

11. Rajakumar C, Agarwal S, Khalil $\mathrm{H}$ et al.: Caesarean scar pregnancy. J Obstet Gynaecol Can 2015; 37: 199.

12. Vial $Y$, Petignat $P$, Hohlfeld P: Pregnancy in a cesarean scar. Ultrasound Obstet Gynecol 2000; 16: 592-593.

13. Godin PA, Bassil S, Donnez J: An ectopic pregnancy developing in a previous caesarian section scar. Fertil Steril 1997; 67: 398-400.
14. Glenn TL, Bembry J, Findley AD et al.: Cesarean scar ectopic pregnancy: current management strategies. Obstet Gynecol Surv 2018; 73: 293-302.

15. Uludag SZ, Kutuk MS, Ak M et al.: Comparison of systemic and local methotrexate treatments in cesarean scar pregnancies: time to change conventional treatment and follow-up protocols. Eur J Obstet Gynecol Reprod Biol 2016; 206: 131-135.

16. Ash A, Smith A, Maxwell D: Caesarean scar pregnancy. BJOG 2007; 114: 253-263.

17. Jurkovic D, Hillaby K, Woelfer B et al.: Cesarean scar pregnancy. Ultrasound Obstet Gynecol 2003; 21: 310.

18. Tamada S, Masuyama H, Maki J et al.: Successful pregnancy located in a uterine cesarean scar: a case report. Case Rep Womens Health 2017; 14: 8-10.

19. Seow KM, Cheng WC, Chuang J et al.: Methotrexate for cesarean scar pregnancy after in vitro fertilization and embryo transfer. A case report. J Reprod Med 2000; 45: 754-757.

20. Haimov-Kochman R, Sciaky-Tamir Y, Yanai N et al.: Conservative management of two ectopic pregnancies implanted in previous uterine scars. Ultrasound Obstet Gynecol 2002; 19: 616-619.

21. Sel G, Sucu S, Harma M et al.: Successful management of cesarean scar pregnancy with vacuum extraction under ultrasound guidance. Acute Med Surg 2018; 5: 358-361.

22. Armstrong V, Hansen WF, Van Voorhis BJ et al.: Detection of cesarean scars by transvaginal ultrasound. Obstet Gynecol 2003; 101: 61-65.

23. Timor-Tritsch IE, Cali G, Monteagudo A et al.: Foley balloon catheter to prevent or manage bleeding during treatment for cervical and Cesarean scar pregnancy. Ultrasound Obstet Gynecol 2015; 46: 118-123.

24. Kim SY, Yoon SR, Kim MJ et al.: Cesarean scar pregnancy; diagnosis and management between 2003 and 2015 in a single center. Taiwan J Obstet Gynecol 2018; 57: 688-691.

25. Timor-Tritsch IE, Monteagudo A, Santos R et al.: The diagnosis, treatment, and follow-up of cesarean scar pregnancy. Am J Obstet Gynecol 2012; 207: 44.e1-44.e13. 